\title{
Intellectual Origins of Islamic Resurgence in the Modern Arab World
}

\author{
Ibrahim M. Abu-Rabi'. SUNY Series in Near Eastern \\ Studies. Albany, NY: State University of New York Press, \\ 1996, $x i i+370 p p$.
}

Most studies of Islamist resurgence have focused on specific aspects of the Islamist political agenda and have sought to identify their intellectual roots in the writings of thinkers from the medieval period of Islamic history. Influenced by Iran's Islamic revolution, these authors have been concerned primarily with political Islam. It is rare to find a book that seeks to establish modern Islamist thought within the context of western critical theory and indigenous political conditions, or that explains its ideas in light of a conflict between revolutionary discourse and state hegemony. Abu-Rabi"s book is thus all the more welcome, as it establishes a basis for consideration of Islamist thinkers that will be an essential reference in the future.

The subject of this book is the thought of Sayyid Qutb, considered within the parameters of Islamic modernism, westernization, orientalism, and the contemporary Islamist response to these factors. Abu-Rabi' says he is undertaking an intellectual history of his subject, that of "a popular religious movement ... f founded by lay Muslim intellectuals" often at odds with the traditional political and religious elites. But he considers this question in light of the "question of continuity and discontinuity in modern Arab thought." Influenced by Foucault, he argues that the question of epistemological acts and thresholds, of conceptual ruptures in the development of ideas, must be countered by the reality of continuities in Islamic thought, by the fact of an ongoing Islamic discourse whose exposition may change according to historical circumstances but whose essence and focus of concern remain constant (pp. 5-6).

The idea of continuity and discontinuity is a valuable method for considering various themes in Arab thought, ranging from the liberal thinkers of the nahdah (renaissance) to both secular and religious Arab responses to the challenge of colonization and the question of how best could ArabIslamic societies survive foreign occupation. Essential here is the question of Arab Muslim "decline," how and why it occurred, and how this decline may be reversed. Abu-Rabi' surveys a variety of Muslim thinkers to posit three approaches to the relevance of Islamic tradition to the resolution of the problem of decline: the rejection of tradition in favor of intellectual stimulus from the West; a conservative approach calling for the "revival of 
the past" in a modern setting: and a middle ground seeking a reconciliation of western thought and the Islamic tradition (p. 40). A key for all strands of thought is the question of tradition, whether it should be rejected, used as the foundation for new departures, or exploited selectively.

This structure forms the basis for discussion of Sayyid Qutb, following a survey of the thought of various thinkers who are identified with the nahdah and a more detailed consideration of the life and thought of Hasan al Bannā. Abu-Rabi", in three extensive chapters, examines "the Pre-Ikhwān Phase" of Qutb's career and thought, Qutb's writings and ideas between 1952-62, and finally “The Qur'anic Contents of Sayyid Qutb's Thought." The touchstone of his analysis is the manner in which Qutb viewed the Qur'an, leading to his extensive discussion and defense of Qutb's Qur'anic exegesis, Fì Zilāl al Qur'ān, which the author regards as "magnificent."

In Abu Rabi"s view, Qutb moved from an aesthetic appreciation of the Qur'an to the belief that it formed the foundation of Islamic thought, ethics, and social practice. The major transitional work in this progression was Social Justice in Islam, which signified an ideological shift in his approach to Egypt and to Islam generally. Here Abu-Rabi' brings in his concern with the role of intellectuals in society, arguing that Qutb can be considered an "organic intellectual" in Gramscian terms, identifying with his peasant background while articulating grievances that could attract the attention of those from other milieus. Qutb defended Islamic tradition and sought to reestablish bonds between contemporary society and the formative Islamic period when faith and practice were one, unhindered by the mediation of a religious hierarchy. This last stipulation reflected Quṭ's and al Bannā's distrust of al Azhar and ulama generally as agents of the state rather than of Islam.

Qutb's life clearly changed with the publication of Social Justice in Islam. Although situated in his "pre-Ikhwān phase," it revealed a concern for the fate of the Muslim masses, ignored by western exploitative political and economic systems, that would remain and intensify for the rest of his life. As Abu-Rabi' makes clear, Qutb's thought developed with specific reference to his own historical-social experience. He argues, against most other scholars, however, that Qutb's ideas were essentially the result of his own approach to the Qur'an and his response to social crisis, not a product of his reading of other thinkers such as Ibn Taymīyah or Mawdudi. This assertion is difficult to prove or refute. It is a strength of this book that Abu-Rabi' situates Qutb's thought as a product of his own internal intellectual journey in response to the pressure of external crises in Egyptian politics and society, but the possibility of external influences derived from other writers is usually rejected rather than investigated. This approach reflects the author's vision of Qutb as a unique thinker, but it tends to isolate Qutb from the intellectual world of Islamic thought, with which he was undoubtedly familiar.

The touchstone of Qutb's life was his imprisonment during the Nasser years, during which he wrote Milestones and Fì Ziläl al Qur'än. Abu-Rabi` defends Qutb against the charges of such scholars as Emmanuel Sivan that his Qur'anic exegesis was unoriginal and rejected modernity. In contrast, 
Abu-Rabi' mounts a powerful argument defending the originality of Qutb's ideas. He contends further that Qutb's rejection of Arab nationalism and his thesis that the Qur'an formed the only logical basis for reestablishing a truly Islamic society was apt; only then could Islam confront and engage modernity, if only to destroy that modernity that Qutb depicted as jähiliyah.

Abu-Rabi“ stresses Qutb's commitment to ijtihad as the basis of a "dynamic fiqh," using the bases of Islamic thought and belief to both reject constructs based on Islamic philosophy and those reflecting western intellectual models; Islam should rely on what Abu-Rabi calls a new theology that has major ideological implications for Islamic society. Here also AbuRabi' engages the question of jihad, acknowledging Qutb's debt to Mawdudi, as a means of defending true Islam as a revolutionary faith-ideology ('aqidah). Beyond this, however, jihad is "a call for an international social revolution" (p. 195) enabling the spread of Islam, which is the sole means of human liberation globally, not only in the Islamic world.

Abu-Rabi concludes his book with a discussion of what he calls an "Islamic Liberation Theology," the thought of the Shi'i thinker Muhammad Husayn Faḍl Allāh. He sees Faḍl Allāh as being influenced by Fanon and Marx as well as by Khomeini, Shari'ati, al Bannā, and Qutb. Confronted by the problem of state disintegration in Lebanon, Faḍl Allāh differs from the Ikhwān in that he sees the committed ulama as the basis of Islamic revival, not its obstacle. He also calls for an individualistic Islamic resurgence where necessary, in contrast to Qutb's call for an Islamic state, and he appreciates the value of elements of western civilization that should be investigated and understood, again in contrast to Qutb.

Abu-Rabi' then returns to the question of continuities and ruptures in Islamic thought. Islam today is central to the discourse of secularists as well as religious thinkers, the result of the crisis of the nation-state in the ArabIslamic world that preexisted but was accentuated by the 1967 Arab defeat by Israel. He does not pursue the implication of this analysis, which suggests, as does his discussion of Faḍl Allāh's thought, that a continued Islamic resurgence contains within it the seeds of jihad against Israel, a war that Faḍl Allāh believes is justified further by the 1993 Israel-PLO accord.

Abu-Rabi' has written a major study. One hopes that it will encourage scholars to engage Islamic thinkers who confront their own environments and western civilization with the same respect they would give western intellectuals who, in the past, have challenged the traditional bases of the European social order. In order to accomplish this task, however, scholars must accept the fact that Islamism responds to the West as a threatening civilization whose past includes imperial expansion and conquest. Westocentric scholars will not wish to do this.

Abu-Rabi‘ has undertaken this task not to extract Qutb from his Egyptian-Islamic milieu but rather to establish Qutb's intellectual effort at a level comparable to that identified with western thinkers. All are products of their societies and their times, positing solutions to perceived crisis that 
they view in metahistorical terms, but in ways that indicate their being situated in specific times and places. In the process, he seems to identify, officially, with Qutb rather than to maintain distance while analyzing his thought.

Abu-Rabi"s book commands our respect and attention as much for the intellectual framework proposed as for his intensive analysis of Qutbian thought. He is correct to argue that Qutb strove to embrace modernity, albeit in a manner suitable to his own vision of true Islam. Whether Qutb's Qur'anic exegesis will become the foundation of this Islamic modernity remains open to question. Likewise, several matters remain unresolved or unengaged, such as how representative was Qutb of Ikhwānist thought? Abu-Rabi` suggests he was the Ikhwān's major spokesman, but his own evidence, especially the views of Hasan Hudaybì who succeeded al Bannã as the ikwān's leader, indicates that the Ikhwān leadership viewed Qutb as an extremist, a unique thinker rather than one they embraced. Likewise, the definition of the intellectual remains problematic. Due to his vocation, al Bannā was led to address and to engage the masses directly; Qutb's circumstances and temperament suggest that he would have written in isolation from them, even while expressing concern for their fate. Social Justice in Islam, written in Qutb's pre-Ikhwān phase, appears to be more representative of mainstream Ikhwanist thought than his later writings, especially his ultimate condemnation of contemporary Islamic society as jāhiliyah.

A final question, outside the concern of this book as an intellectual history but relevant to Qutb's own vision of the future, is what type of society would emerge if led by people who followed Qutb? Would the exercise of creative ijtihad be extended to the many or restricted to the few? Would this few be an elite who spoke in the name of the people while suppressing disagreement in the name of Islam, or would a broader debated be tolerated? Qutb's prison experience, as the touchstone of his later writings, suggests a penchant for autocracy coupled with a determination to conquer the non-Muslim world in the name of Islamic justice and egalitarianism, demanding the right to proselytize but withholding that right from those who would oppose Islam. This aspect of jihad is alluded to but not elaborated upon in this book. It is one facet of Qutb's thought, along with his vision of modern jahiliyah, that other Islamist thinkers have criticized, a fact often ignored by western scholars who have tended to generalize Islamism from his writings.

It is to Abu-Rabi"s credit that he calls attention to these disagreements within contemporary Islamist thought. Qutb's life and writings may serve ultimately to engage Islamist intellectuals in dialogues where disparate approaches and responses to the question of what is an Islamic society will be tolerated. This would not be Qutb's preference, but it reminds us of the plurality of views existing within the Islamist spectrum. All may agree on "resurgence" as the means to self and social Muslim reassertion against foreign encroachment, but the nature of that resurgence and its impact on the 
state remain open to interpretation, one final distinction that places us in Abu-Rabi"s debt.

Charles D. Smith

Near Eastem Studies

University of Arizona

Tucson, Arizona 